\title{
Erratum
}

\section{A Simple Zinc-Mediated Preparation of Selenols}

Claudio Santi,* Stefano Santoro, Lorenzo Testaferri, Marcello Tiecco Synlett 2008, 1471.

In Table 3 entry 4, the structure of compound 15 was given incorrectly as $\mathrm{Me}\left(\mathrm{CH}_{2}\right)_{5} \mathrm{CH}_{3}$. The correct product of this reaction is $\mathrm{PhSe}\left(\mathrm{CH}_{2}\right)_{5} \mathrm{CH}_{3}$. 